\title{
Physicochemical and sensory properties of Yakhobak (Cucurbita maxima subsp. maxima) paste under different high pressure heating conditions
}

\author{
Bo-Ram Park*, Na-Jeong Kim, Su-Jeong Choi, Gui-Jung Han, Ha-Yun Kim \\ Department of Agrofood Resources, National Institute of Agricultural Science, Rural Development Administration, \\ Jeonju 54875, Korea
}

\section{가열조건에 따른 약호박(Cucurbita maxima subsp. maxima) 페이스트의 이화학적 관능적 품질특성}

\author{
박보람* · 최수정 · 김나정 · 한귀정 · 김하윤 \\ 농촌진흥청 국립농업과학원 농식품자원부
}

\begin{abstract}
For the production of Yakhobak (Cucurbita maxima subsp. maxima) paste under various heating conditions, we steamed Yakhobak for roughly $20 \mathrm{~min}$, followed by heating under high pressure treatment for 0 min (HHP0), 20 min (HHP20), $40 \mathrm{~min}$ (HHP40), and $60 \mathrm{~min}$ (HHP60). The physicochemical and sensory characteristics were subsequently investigated. Generally, no significant difference was observed in organic acid content and sensory characteristics score between Yakhobak paste treated with and without high-pressure heating. However, there was a significant difference in color value, soluble solids, and free sugar content. The $L$ value for color of the group HHPO, untreated control Yakhobak paste (no high-pressure heating), decreased as time increased from 20 min to 60 min, with $L$ values of 44.33, 44.25, and 42.86, respectively. The b value for the color of Yakhobak paste also decreased, showing a significant difference. Soluble solids and free sugar (fructose, glucose, sucrose) contents of the high-pressure heat-treated groups HHP20, HHP40, and HHP60 decreased compared with untreated group HHP0. Organic acid composition of Yakhobak paste included citric acid, malic acid, and fumaric acid, and the major organic acid was malic acid. Sensory score of HHP40 was the highest among all experimental groups in terms of overall preference, but there was no significant difference.
\end{abstract}

Key words : Yakhobak, paste, high-pressure heating

\section{서 론}

한국에서 재배하는 호박(Cucurbita spp.)은 박과에 속하 는 일년생 덩굴성 초본으로 중앙아메리카 또는 멕시코 남부 의 열대 아메리카 원산의 동양계 호박(C. moschata), 남아메 리카 원산의 서양계 호박(C. maxima), 멕시코 북부와 북아

*Corresponding author. E-mail : bboram27@korea.kr Phone : 82-63-238-3566, Fax : 82-63-238-3842

Received 28 November 2016; Revised 6 January 2017; Accepted 6 January 2017.

Copyright (c) The Korean Society of Food Preservation. All rights reserved.
메리카 원산의 페포계 호박(C. pepo), 동양계 호박에 포함되 었으나 독립종으로 분리된 멕시코 중동부 원산의 믹스타 호박(C. mixta) 및 멕시코 중남부 원산의 흑종 호박 $(C$. ficifolia)인 5 개의 재배종으로 분류된다. 그 중 식용으로 주 로 재배되고 있는 종은 동양계, 서양계 및 페포계 호박이며, 우리나라에서 일반화된 동양계 호박은 늙은호박이 있고, 서양계 호박으로는 단호박 또는 밤호박이 대표적이다(1). 호박은 품종에 따라 형태나 맛이 다르고 일반성분 및 영양성분에 차이는 있지만 식이섬유가 다량 함유되어있어 당분의 소화흡수를 지연시키고(2), 혈당강하에 도움을 줄 수 있는 물질을 가져 혈당상승을 억제하므로 당뇨에 유용하 게 작용할 수 있으며(3), 지방세포의 축적 및 분화를 억제하 
여 항비만 소재로서 이용될 수 있다(4). 특히 호박에 다량 함유되어있는 베타카로틴으로 인해 항암(5), 항산화(6) 등 의 약리적 효과를 지니고 과육뿐만 아니라 잎, 줄기 및 호박 씨에서도 생리활성물질을 얻을 수 있어 호박에 대한 긍정적 인 관심이 지속되고 있다(7).

이러한 다양한 효능을 지닌 호박을 이용한 식품 개발 및 그 가공방법에 관한 연구로는 늙은 호박 비율에 따른 양갱의 영양성분분석(8), 단호박 가루를 첨가하여 제조한 호상요구르트(9), 쿠키(10) 및 국수(11)의 품질특성, 단호박 첨가수준에 따른 식혜의 품질특성(12), 호박고추장의 숙성 중 성분변화 및 관능적 특성연구(13) 등이 보고되었고, 다양 한 품종에 대한 영양성분 비교 및 그 품질특성에 관한 연구 $(1,2)$ 도 보고되었다.

한편, 약호박(C. maxima subsp. maxima, IT178686)은 1993년 농업유전자원정보센터에 서양계 호박으로 등록되 었으나 널리 재배되지 않고 이에 대해 모르는 소비자들이 많아 약호박의 소비뿐만 아니라 기초적인 연구도 미비한 상황이다. 우리나라에서 대표적인 서양계 호박인 단호박과 그 크기 및 과실 모양은 비슷하나 약호박은 과피가 빨강고 당도가 약하며 과육색은 백녹색으로 그 형태가 다르다. 시 중에서는 기관지 기능을 개선시키는데 도움을 준다고 알려 져 있으나 약호박에 대한 연구는 호박의 품종별 일반성분, 무기질 및 비타민함량 비교에 대한 연구(2) 이외에 전무한 실정이다.

최근에는 식품을 손쉽게 제조하기 위하여 원재료를 퓨 레, 페이스트, 농축액 및 분말 등의 균일한 상태로 만든 것을 식품 소재라고 하고 이에 관심이 증가되고 있다. 식품 소재화는 현대인의 여가 시간의 확대, 농촌의 체험 프로그 램을 통한 관광산업 활성화, 편이식품시장 확대 등에 유용 하게 적용될 수 있으며, 이를 이용하여 사회적, 경제적으로 식품산업이 발전할 수 있는 계기가 된다. 그 예로 수산물 중 붉은 대게가 조직감이 부드럽고 맛이 담백하며 다른 게류에 비해 비교적 갑각의 조직이 유연해 근육의 분리가 용이하지만, 해마다 자원이 감소하고 식품원료로서의 이용 범위에 한계가 있으며 근육의 저수율에 의해 단가 상승이 불가피하기 때문에 이를 효율적으로 이용하기 위하여 페이 스트를 제조하고 식품소재로의 가능성을 연구(14)하였다. 또한 농산물의 식품소재화의 예로 다양한 생리활성을 가지 는 마늘의 기호 저하를 유발시키는 자극적인 냄새를 제거하 기 위해 녹차를 첨가하고 현대인의 칼슘섭취 필요성에 의해 칼슴을 첨가한 마늘페이스트를 제조하여 식품소재로서의 개발 가능성을 검토하였고(15), 단호박을 페이스트로 가공 하기 위한 최적조건을 설정하기 위해 고압가열처리 유무와 처리시간에 따라 이화학적 품질특성 변화를 확인(16)하였 다.

본 연구는 약호박이 기관지 개선 및 기침가래에 효능을 보인다고 알려져 있으나 이에 대한 가공·조리에 관한 연구
는 전무하므로 가열조건을 달리하여 약호박 페이스트를 제조하고 이의 품질특성 변화를 조사함으로써 약호박 이용 시 편이성을 높이고, 식품소재로서 다양한 용도로 쓰이기 위한 기초자료를 마련하고자 하였다.

\section{재료 및 방법}

실험 재료

본 실험에서 사용한 약호박(C. maxima subsp. maxima, IT178686)은 중량이 $1,450 \pm 50 \mathrm{~g}$ 으로 당도 $3.53 \pm 0.06{ }^{\circ} \mathrm{Brix}$, 경도 $564.70 \pm 167.87 \mathrm{~g} / \mathrm{cm}^{2}$ 인 것으로 충북 진천의 바노들 농장에서 생산된 것으로 (주)세계종묘에서 판매하는 '약호 박, 종자를 구입하여 재배한 것이다. 약호박 페이스트의 유리당 및 유기산 분석에 이용된 fructose, glucose, sucrose, maltose, citric acid, malic acid, succinic acid, fumaric acid 등은 Sigma-Aldrich Co.(St. Louis, MO, USA)에서 구입하였 고, 그 밖의 시약은 analytical 및 HPLC 등급을 사용하였다.

\section{약호박 페이스트의 제조}

약호박 페이스트는 Fig. 1과 같이 약호박을 깨끗하게 세 척하여 껍질과 속을 제거하고 일정크기로 절단하였다(16).

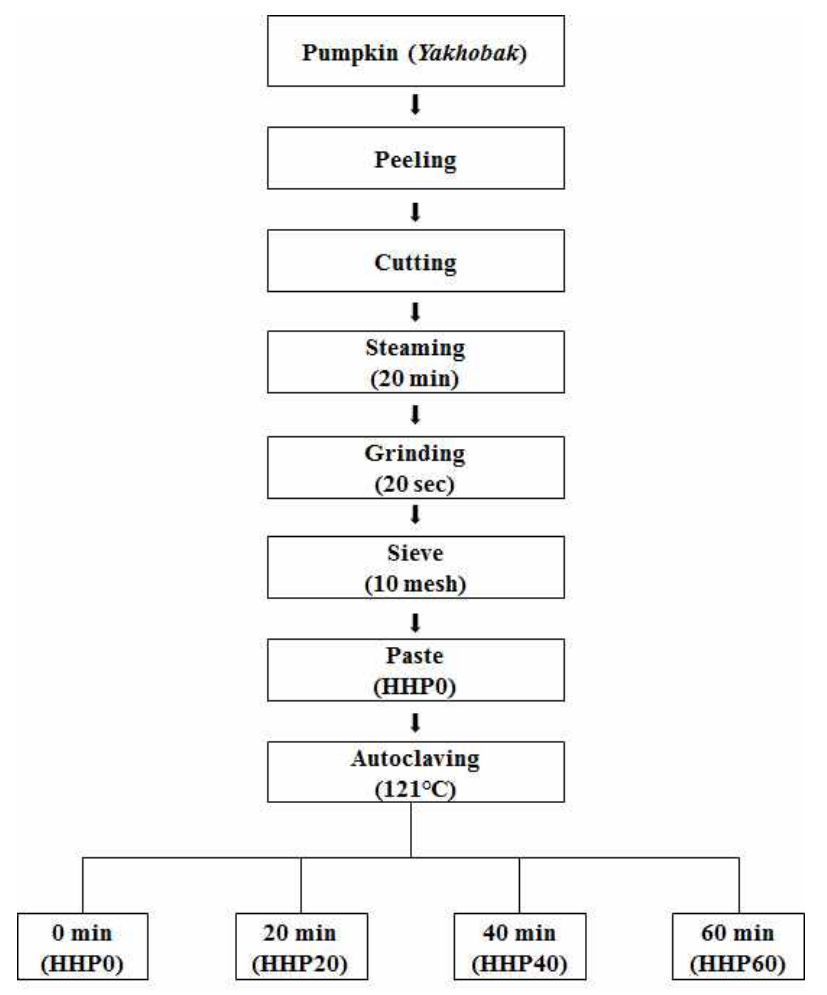

Fig. 1. Preparation process of Yakhobak paste with different heating time under high pressure heating time.

$\mathrm{HHPO}$, high pressure heating pumpkin $0 \mathrm{~min}$; HHP20, high pressure heating pumpkin $20 \mathrm{~min}$; HHP40, high pressure heating pumpkin $40 \mathrm{~min}$; HHP60, high pressure heating pumpkin $60 \mathrm{~min}$. 
찜기에 시료 $1 \mathrm{~kg}$ 기준 $200 \mathrm{~mL}$ 의 물을 이용하였고 강한 불에서 10 분 동안 증기로 가열한 후 약한 불로 줄여 10 분 동안 계속 가열하였다. 가열과정 후 일정시간 식힌 뒤 믹서 기(HR2195, PHILIPS, Amsterdam, Netherlands)로 20초 간 마쇄한 후 $10 \mathrm{mesh}$ 체로 내렸다. 이렇게 증숙, 마쇄하여 균질화된 약호박 $500 \mathrm{~g}$ 을 $1 \mathrm{~L}$ 병(Laboratory bottle, DURAN®, Mainz, Germany)에 담아 뚜껑을 살짝 덮고 호일 로 덮은 뒤 autoclave(Maxterile 60, DAIHAN-brand®, Wonju, Korea)를 이용하여 $121^{\circ} \mathrm{C}$ 에서 0 분(high pressure heating pumpkin, HHP0), 20 분(HHP20), 40 분(HHP40), 60 분 (HHP60)간 처리시간을 달리하여 고압가열하는 방법으로 가열 조건 별 약호박 페이스트를 제조하였다.

\section{약호박 페이스트의 색도}

가열 조건을 달리한 약호박 페이스트의 색도는 시료를 petridish $(50 \times 12 \mathrm{~mm})($ Cell culture dish, SPL Life Sciences Co., Ltd., Pocheon, Korea)에 넣은 다음 색차계(Color i7, X-rite Inc., GrandRapids, MI, USA)를 이용하여 Hunter value 인 $\mathrm{L}$ value(명도, lightness), a value(적색도, redness) 및 $\mathrm{b}$ value(황색도, yellowness)를 6회 측정한 뒤 평균값을 나타 내었고, 색차를 구하기 위해 사용된 식은 아래와 같으며 이때 사용된 standard plate의 L값은 95.73 , a값은 $-0.15, \mathrm{~b}$ 값 은 2.82 이었다.

$$
\Delta E=\sqrt{\left(L-L^{\prime}\right)^{2}+\left(a-a^{\prime}\right)^{2}+\left(b-b^{\prime}\right)^{2^{2}}}
$$

\section{약호박 페이스트의 가용성고형분}

처리 조건을 달리한 호박페이스트를 각 시료 $1 \mathrm{~g}$ 을 일정 하게 취하여 디지털당도계(PAL-1, Atago Co., Ltd., Tokyo, Japan)를 이용하여 ${ }^{\circ} \mathrm{Brix}$ 로 3 회 반복 측정하였다.

\section{약호박 페이스트의 유리당}

가열시간을 달리한 약호박 페이스트의 유리당 함량은 각 시료 $2 \mathrm{~g}$ 에 증류수 $50 \mathrm{~mL}$ 를 넣고 30 분간 초음파 추출한 후 원심 분리하여 얻어진 상등액을 $0.20 \mu \mathrm{m}$ membrane filter(Whatman nylon syringe filter, GE healthcare, Buckinghamshire, UK)로 여과하여 HPLC system(Agilent Technologies 1260 infinity, Palo Alto, CA, USA)으로 유리당 함량과 조성을 측정하였다(17). HPLC 분석조건은 $\mathrm{NH} 2$ column(Shodex Asahipak NH2P-50 4E column, Kanagawa, $\mathrm{Japan})(4.6 \times 250 \mathrm{~mm}, 5 \mu \mathrm{m})$ 를 사용하였고, 검출기는 $\mathrm{ELSD}$ (Palo Alto, CA, USA)를 사용하였으며, 이동상은 acetonitrile:water(70:30, \%(v/v))를 $1.2 \mathrm{~mL} / \mathrm{min}$ 속도로 흘려 주었고 $10 \mu \mathrm{L}$ 를 주입하여 분석하였다. 표준물질로는 fructose, glucose, sucrose(Sigma Co., St. Louis, MO, USA)를 사용하였다.

\section{약호박 페이스트의 유기산}

가열시간을 달리한 약호박 페이스트의 유기산 함량은 각 시료 $2 \mathrm{~g}$ 에 증류수 $50 \mathrm{~mL}$ 를 넣고 30 분간 초음파 추출한 후 원심 분리하여 얻어진 상등액을 $0.20 \mu \mathrm{m}$ membrane filter(Whatman nylon syringe filter, GE healthcare)로 여과하 여 HPLC system(Agilent Technologies 1260 infinity)으로 유기산 함량과 조성을 측정하였다(18). 칼럼은 Aminex HPX-87H ion exclusion column $(7.8 \times 300 \mathrm{~mm}$, Bio-Rad, Hercules, CA, USA)을 사용하였고 검출기는 UV detector로 $215 \mathrm{~nm}$ 에서 검출하였으며, 이동상은 $0.008 \mathrm{~N}$ sulphuric acid 용액을 $0.6 \mathrm{~mL} / \mathrm{min}$ 유속으로 흘려주었고 $20 \mu \mathrm{L}$ 를 주입하여 분석하였다. 표준물질로 citric acid, malic acid, succinic acid 및 fumaric acid를 사용하였다.

\section{약호박 페이스트 관능검사}

가열시간을 달리한 약호박 페이스트의 관능검사는 여러 번의 예비실험을 통해 훈련된 농식품자원부 연구원 15 명의 패널 요원을 대상으로 실험의 목적과 평가항목에 대해 설명 한 다음 약호박 페이스트의 기호도 평가를 실시하였다. 평 가항목은 색(color), 향(flavor), 부드러움(softness), 단맛 (sweetness), 감칠맛(savory taste), 전반적인 기호도(overall acceptability)에 대한 특성이었고, 특성차이검사와 기호도 검사로 나누어 평가하였다. 평가방법은 9점 척도법(1점, 대단히 약하다(나쁘다); 5 점, 보통이다; 9점, 대단히 강하다 (좋다))으로 평가항목의 강도 및 선호도가 높을수록 높은 점수를 주도록 평가하였다. 시료는 일회용 접시에 무작위 로 조합된 난수표를 기입하고 $5 \mathrm{~g}$ 씩 담아 뚜껑을 덮고 물과 함께 제공하였다.

\section{통계처리}

모든 실험의 통계처리는 12.0 Statistical Package for Social Sciences(SPSS, SPSS Inc., Chicago, IL, USA) software package 프로그램을 사용하였으며 측정값은 기술 통계분석으로 평균값과 표준편차를 산출하였다. 시료간의 유의성 검정은 일원배치분산분석(one-way ANOVA)을 실 시한 후, Duncan's multiple range test를 실시하여 $p<0.05$ 수준에서 확인하였다.

\section{결과 및 고찰}

\section{가열조건에 따른 약호박 페이스트의 색도}

가열조건에 따른 약호박 페이스트의 색도측정 결과는 Table 1과 같으며, 이때 생 약호박의 색도와 비교를 위해 함께 나타내었다. 생 약호박의 색도는 L 값이 45.04 , a 값이 $25.53, \mathrm{~b}$ 값이 77.10 으로 나타났다. Kim 등(19)의 연구에 따르면 늙은 호박의 $\mathrm{L}, \mathrm{a}$ 및 $\mathrm{b}$ 값은 각 각 $73.3,14.0$ 및 
이당류 sucrose가 증숙 및 고압가열 과정을 거친 페이스트 에서는 검출된 결과는 Choi 등(25)의 생마늘의 증숙과정에 서 sucrose의 함량이 증가하였다고 보고한 결과와 유사하였 다. 또한 Shin 등(26)은 마늘을 열풍건조 처리하였을 때 glucose, fructose의 함량이 감소하였는데, 이러한 감소 경향 은 예열처리 온도가 높을수록 커지며 단당류의 경우 그 폭이 더 크다고 하였고, 이당류인 sucrose는 단당류와 반대 로 증가하는 경향을 나타내어 이와 같은 당의 변화는 fructooligosaccharide가 이당류 및 단당류로 분해되고 fructose와 glucose는 화학반응에 의하여 분해 또는 소멸된 다고 설명하였다.

따라서, 약호박 페이스트의 장시간 고압가열처리는 총 유리당 함량을 감소시키는 결과를 가져오므로 전처리방법 으로 바람직하지 않다고 사료되며 단시간의 증숙 과정이 약호박의 유리당 함량 증가에 도움이 되는 것으로 보인다.

Table 3. Free sugars of fresh pumpkin and pumpkin paste with different heating time under high pressure

\begin{tabular}{ccccc}
\hline \multirow{2}{*}{ Sample ${ }^{1)}$} & \multicolumn{3}{c}{ Free sugars $(\mathrm{mg} / 100 \mathrm{~g})$} & \multirow{2}{*}{ Total } \\
\cline { 2 - 4 } & Fructose & Glucose & Sucrose & \\
\hline Fresh & $429.2 \pm 23.5^{\mathrm{b} 2)}$ & $584.3 \pm 42.6^{\mathrm{b}}$ & $\mathrm{ND}^{3)}$ & $1013.5 \pm 32.2^{\mathrm{c}}$ \\
HHP0 & $543.5 \pm 47.5^{\mathrm{a}}$ & $750.7 \pm 53.3^{\mathrm{a}}$ & $119.2 \pm 2.3^{\mathrm{a}}$ & $1413.4 \pm 98.7^{\mathrm{a}}$ \\
HHP20 & $454.6 \pm 34.3^{\mathrm{b}}$ & $591.1 \pm 26.3^{\mathrm{b}}$ & $90.8 \pm 9.2^{\mathrm{b}}$ & $1136.5 \pm 42.1^{\mathrm{b}}$ \\
HHP40 & $425.1 \pm 6.9^{\mathrm{b}}$ & $547.8 \pm 11.2^{\mathrm{b}}$ & $95.9 \pm 15.5^{\mathrm{b}}$ & $1068.9 \pm 30.8^{\mathrm{bc}}$ \\
HHP60 & $425.8 \pm 17.1^{\mathrm{b}}$ & $565.7 \pm 46.8^{\mathrm{b}}$ & $67.3 \pm 3.1^{\mathrm{c}}$ & $1058.8 \pm 39.6^{\mathrm{bc}}$ \\
\hline
\end{tabular}

${ }^{1)} \mathrm{HHPO}$, high pressure heating pumpkin $0 \mathrm{~min}$; HHP20, high pressure heating pumpkin $20 \mathrm{~min}$; HHP40, high pressure heating pumpkin $40 \mathrm{~min}$; HHP60, high pressure heating pumpkin $60 \mathrm{~min}$.

2)a-c Different letters within the same column are significantly different from each other at $p<0.05$ by Duncan's multiple range test.

${ }^{3)} \mathrm{ND}$, not detected.

\section{가열조건에 따른 약호박 페이스트의 유기산}

가열조건에 따른 약호박 페이스트의 비휘발성 유기산 조성 및 함량을 분석한 결과는 Table 4 와 같으며, 이 때 생약호박의 비휘발성 유기산 조성 및 함량은 비교를 위해 함께 나타내었다. 생 약호박의 유기산은 malic acid > succinic aicd $>$ citric acid $>$ fumaric acid 순으로 4종이 검출 되었고, malic acid가 주요 유기산으로 그 함량이 286.1 $\mathrm{mg} / 100 \mathrm{~g}$ 으로 가장 높아 전체 유기산의 약 $67 \%$ 를 차지하였 으며 succinic acid가 $73.5 \mathrm{mg} / 100 \mathrm{~g}$, citric acid가 $41.0 \mathrm{mg} / 100$ $\mathrm{g}$, fumaric acid가 $25.5 \mathrm{mg} / 100 \mathrm{~g}$ 의 값을 나타내었다. Kim 등(19)은 단호박의 주요 유기산이 succinic acid이고, 늙은 호박은 malic acid라 한 것으로 보아, 약호박의 주요 유기산 은 늙은 호박과 동일하나, 총 유기산 함량에서 차지하는 비중과 유기산의 구성에서 tartaric acid가 검출되지 않은 점 등 차이가 있었다. 일반적으로 호박산이라고 불리는 succinic acid는 호박에서 처음 추출해내었다고 하여 호박산
이라 명명하였고, 식물계에 널리 존재하며 호박의 건류에 의해 얻을 수 있는 산으로 알려져 있는데(23) 약호박의 succinic acid 함량은 총 유기산 함량의 약 $17 \%$ 로 나타났으 며, 오히려 증숙 및 고압가열 처리한 약호박 페이스트에서 는 succinic acid가 검출 되지 않았다. 증숙 과정을 거친 약호박 페이스트(HHP0)의 유기산은 malic acid > citric acid $>$ fumaric acid 순으로 3종이 검출되었고, 증숙 후 20-60분간 고압가열 처리한 실험군(HHP20, HHP40, HHP60)의 유기 산 조성 및 함량 또한 이와 같았으며 증숙처리 실험군 (HHP0)과 유의적인 차이가 없었을 뿐 아니라 처리시간에 따른 차이는 없는 것으로 나타났다. $\mathrm{HHPO}$ 의 malic acid 함 량은 $426.7 \mathrm{mg} / 100 \mathrm{~g}$ 으로 생 약호박에 비하여 총 유기산 함량 대비 $20 \%$ 가량 유의적으로 증가하였으며, 총 유기산 함량 또한 $490.0 \mathrm{mg} / 100 \mathrm{~g}$ 으로 유의적으로 증가하였으나 $(\mathrm{p}<0.05)$, fumaric acid 함량이 큰 폭으로 감소하였고 succinic acid가 검출되지 않았다. 구연산(citric acid)은 상쾌 한 신맛을 내는 성분으로 레몬, 오렌지 등 과일류에 풍부하 게 분포되어있는 유기산으로(24), citric acid의 경우 생 약호 박과 증숙 과정을 거친 페이스트 사이에 유의적인 차이가 나타나지 않았으나 증숙 처리에 의해 그 함량이 증가하였 고, 고압가열 처리시간이 증가함에 따라 함량이 증가하는 경향을 보였는데, 이는 지속적인 열처리로 인하여 sucrose 가 단당류인 fructose로 분해되고 분해된 fructose가 열분해 로 인하여 HMF, furfural 및 5-methyl furfural 등과 유기산으 로 분해되어(27) 약호박 페이스트의 ctric acid 및 총 유기산 함량이 증가한 것으로 판단된다. 총 유기산 함량 또한 유리 당 함량과 마찬가지로 생 약호박에 비해 증숙 및 고압가열 처리에 의해 증가하는 경향을 보였으나 시료 간 유의적인 차이를 보이지는 않았다. 이 결과 증숙 처리는 약호박의 유기산 조성 및 함량에 변화를 주는 것을 확인하였고, 이러 한 유기산의 조성 변화는 약호박 페이스트의 풍미차이에 큰 영향을 끼칠 수 있다고 사료된다.

Table 4. Organic acids (mg/100 g) of fresh pumpkin and pumpkin paste with different heating time under high pressure

\begin{tabular}{|c|c|c|c|c|c|}
\hline \multirow{2}{*}{ Sample ${ }^{1)}$} & \multicolumn{4}{|c|}{ Organic acids } & \multirow{2}{*}{ Total } \\
\hline & Citric acid & Malic acid & Succinic aci & Fumaric acid & \\
\hline Fresh & $41.0 \pm 11.0^{\mathrm{NS} 3)}$ & $286.1 \pm 4.2^{\mathrm{b} 2)}$ & $73.5 \pm 22.4$ & $25.5 \pm 1.9^{\mathrm{a}}$ & $426.1 \pm 29.5^{\mathrm{NS}}$ \\
\hline HHP0 & $59.9 \pm 5.5$ & $426.7 \pm 47.6^{\mathrm{a}}$ & $\mathrm{ND}^{4)}$ & $3.3 \pm 0.4^{b}$ & $490.0 \pm 53.2$ \\
\hline HHP20 & $64.1 \pm 16.8$ & $405.0 \pm 40.3^{\mathrm{a}}$ & $\mathrm{ND}$ & $3.2 \pm 0.1^{b}$ & $472.4 \pm 55.1$ \\
\hline HHP40 & $65.2 \pm 14.0$ & $406.6 \pm 7.8^{\mathrm{a}}$ & $\mathrm{ND}$ & $3.2 \pm 0.1^{b}$ & $475.0 \pm 6.6$ \\
\hline HHP60 & $85.0 \pm 30.0$ & $428.9 \pm 23.4^{\mathrm{a}}$ & ND & $2.7 \pm 0.0^{\mathrm{b}}$ & $516.7 \pm 53.4$ \\
\hline
\end{tabular}

${ }^{1)} \mathrm{HHP0}$, high pressure heating pumpkin $0 \mathrm{~min}$; HHP20, high pressure heating pumpkin $20 \mathrm{~min}$; HHP40, high pressure heating pumpkin $40 \mathrm{~min}$; HHP60, high pressure heating pumpkin $60 \mathrm{~min}$

2)a-bifferent letters within the same column are significantly different from each other at $p<0.05$ by Duncan's multiple range test.

${ }^{3)} \mathrm{NS}$, not significant.

${ }^{4} \mathrm{ND}$, not detected. 


\section{가열조건에 따른 약호박 페이스트의 관능적 특성}

가열조건에 따른 약호박 페이스트의 관능적 특성 변화를 확인하기 위해 특성차이 결과를 Table 5에 나타내었다. 증 숙 처리한 약호박 페이스트인 HHP0 실험군의 색의 강도는 5.53 으로 가장 약했고 고압가열 처리 및 그 시간이 증가함에 따라 HHP20 5.80, HHP40 6.07, HHP60 6.07로 색이 강해지 는 경향을 보였으나 유의적인 차이는 없었다 $(\mathrm{p}<0.05)$. 또한 증숙 처리한 약호박 페이스트 대비, 고압가열 처리한 실험 군의 향 특성이 강한 점수를 받았으나 마찬가지로 유의적인 차이는 없었다 $(\mathrm{p}<0.05)$. 부드러움 특성은 증숙 처리한 $\mathrm{HHPO}$ 실험군이 $7.07,20$ 분간 고압가열 처리한 HHP20 실험 군이 7.27로 비슷한 수준이었고, HHP40 실험군이 6.73, HHP60 실험군이 6.73으로 오히려 감소하였으며, 단맛과 감칠맛 특성은 40 분간 고압가열 처리한 HHP40 실험군이 각 각 $2.60,3.47$ 로 높았으나 모두 유의적이 차이가 없었고 $(\mathrm{p}<0.05), 5$ 점(보통이다) 이하로 평가된 것으로 보아 단맛과 감칠맛이 현저히 낮은 것으로 판단된다.

Table 5. Attribute difference of pumpkin paste with different heating time under high pressure

\begin{tabular}{cccccc}
\hline Characteristics & $\mathrm{HHP}^{1)}$ & $\mathrm{HHP} 20$ & $\mathrm{HHP} 40$ & $\mathrm{HHP60}$ & F-value \\
\hline Color & $5.53 \pm 0.99$ & $5.80 \pm 0.94$ & $6.07 \pm 0.80$ & $6.07 \pm 1.39$ & 0.883 \\
Flavor & $5.27 \pm 1.75$ & $6.40 \pm 1.35$ & $6.60 \pm 1.24$ & $6.40 \pm 2.10$ & 2.042 \\
Softness & $7.07 \pm 1.39$ & $7.27 \pm 1.22$ & $6.73 \pm 1.49$ & $6.73 \pm 2.02$ & 0.429 \\
Sweetness & $2.00 \pm 0.85$ & $2.47 \pm 1.30$ & $2.60 \pm 0.99$ & $2.27 \pm 1.03$ & 0.919 \\
Savory taste & $2.80 \pm 1.42$ & $3.20 \pm 1.93$ & $3.47 \pm 2.03$ & $3.40 \pm 1.72$ & 0.420 \\
\hline
\end{tabular}

${ }^{1)} \mathrm{HHPO}$, high pressure heating pumpkin $0 \mathrm{~min}$; HHP20, high pressure heating pumpkin $20 \mathrm{~min}$; HP40, high pressure heating pumpkin $40 \mathrm{~min}$; HHP60, high pressure heating pumpkin $60 \mathrm{~min}$.

가열조건에 따른 약호박 페이스트의 기호도 검사 결과는 Table 6과 같다. 증숙 처리한 약호박 페이스트인 HHP0 실험 군의 색의 기호도는 6.53 으로 가장 높았고, 고압가열 처리 및 그 시간이 증가함에 따라 HHP20 6.13, HHP40 6.00, HHP60 5.73으로 점점 감소하는 경향을 보였으나 유의적인 차이는 없었다(p<0.05). $\mathrm{HHP0}$ 의 향 기호도는 20 분간 고압 가열 처리한 HHP20 실험군과 동일한 점수인 5.20을 받았 고, 40-60분간 고압가열 처리한 실험군이 5.93-5.73으로 약 간 높았으나 이 또한 유의적인 차이는 없었다 $(\mathrm{p}<0.05)$. 부드 러운 맛, 단맛, 감칠맛 기호도 모두 특정한 가열조건을 선호 하는 경향을 찾을 수 없었으며 40 분간 고압가열 처리한 $\mathrm{HHP} 40$ 실험군의 전반적 기호도 점수가 가장 우수하였으나 유의성이 없고, 4.33 으로 5점(보통이다) 이하로 나타났다. 이는, 약호박은 단호박과 달리 가용성 고형분이 낮기 때문 인 것으로 보이며, 페이스트 제조 시 증숙 및 0-60분 고압가 열 처리를 통한 기호도 개선 효과는 없는 것으로 보인다. 따라서 약호박의 기호도를 높이기 위한 페이스트 가공을
위해서는 감미료 등 부재료 첨가를 통한 약호박 페이스트의 맛 개선이 필요할 것으로 판단된다.

또한, 본 연구 결과 20 분간 증숙 처리한 약호박 페이스트 의 가용성 고형분, 총 유리당 함량, 총 유기산 함량이 가장 높았고, 고압가열 처리와 그 지속시간에 따른 관능적 특성 이 크게 개선되지 않은 것으로 보아 약호박을 이용한 페이 스트 소재를 제조하기 위한 장시간의 고압가열 처리는 불필 요할 것으로 사료되나, 홍삼(28), 마늘(29) 등 과채류(30,31) 의 고압가열처리 가공 시 유용한 생리활성물질이 생성에 대한 연구가 보고된 바와 같이 약호박 또한 추가 실험을 통해 각종 영양성분의 함량변화를 확인하기 위한 연구가 필요한 것으로 보인다.

Table 6. Preference of pumpkin paste with different heating time under high pressure

\begin{tabular}{cccccc}
\hline Characteristics & $\mathrm{HHP0}^{1)}$ & $\mathrm{HHP20}$ & $\mathrm{HHP} 40$ & $\mathrm{HHP} 60$ & F-value \\
\hline Color & $6.53 \pm 1.19$ & $6.13 \pm 1.25$ & $6.00 \pm 1.07$ & $5.73 \pm 0.88$ & 1.365 \\
Flavor & $5.20 \pm 1.61$ & $5.20 \pm 1.70$ & $5.93 \pm 1.87$ & $5.73 \pm 2.15$ & 0.618 \\
Softness & $5.87 \pm 1.68$ & $6.00 \pm 1.36$ & $5.73 \pm 1.10$ & $5.47 \pm 0.99$ & 0.452 \\
Sweetness & $2.60 \pm 1.06$ & $2.73 \pm 1.39$ & $2.73 \pm 1.33$ & $2.53 \pm 1.25$ & 0.094 \\
Savory taste & $2.87 \pm 1.41$ & $2.67 \pm 1.50$ & $3.07 \pm 1.49$ & $2.87 \pm 1.55$ & 0.181 \\
Overall preference & $4.00 \pm 1.41$ & $4.27 \pm 1.83$ & $4.33 \pm 1.76$ & $3.67 \pm 1.68$ & 0.490 \\
\hline
\end{tabular}

${ }^{1} \mathrm{HHP} 0$, high pressure heating pumpkin $0 \mathrm{~min}$; HHP20, high pressure heating pumpkin $20 \mathrm{~min}$; HHP40, high pressure heating pumpkin $40 \mathrm{~min}$; HHP60, high pressure heating pumpkin $60 \mathrm{~min}$.

\section{요 약}

약호박을 페이스트로 소재로 활용하기 위한 가열조건을 확인하기 위하여 증숙 후 고압가열 처리 시간을 달리한 약호박 페이스트를 제조하여 색도, 가용성 고형분, 유리당, 유기산 및 관능적 특성을 확인하였다. 그 결과, 색도는 증숙 처리 후 $\mathrm{L}, \mathrm{b}$ 값이 유의적으로 증가하였으나, a 값은 증숙과 고압가열 시간이 증가함에 따라 유의적으로 감소하였으며 페이스트의 고압가열 시간이 증가함에 따라 $\mathrm{L}, \mathrm{a}$ 및 $\mathrm{b}$ value 모두 유의적으로 감소하였다. 가용성 고형분은 증숙 처리 페이스트가 $4.13{ }^{\circ} \mathrm{Brix}$ 으로 생약호박 대비 유의적으로 증가 하였으나, 고압가열 처리 시간이 증가함에 따라 3.97-3.80 ${ }^{\circ} \mathrm{Brix}$ 으로 유의적으로 감소하는 경향을 보였다 $(\mathrm{p}<0.05)$. 유 리당은 증숙 처리 후 sucrose가 추가적으로 검출되었으며, HHP0 실험군의 fructose, glucose 및 sucrose 함량이 가열조 건별 약호박 페이스트 중 유의적으로 가장 높은 값을 나타 내었고 $(\mathrm{p}<0.05)$, 고압가열시간이 증가함에 따라 fructose의 값은 유의적으로 감소하였고, glucose는 HHP40 실험군이 유의적으로 가장 낮은 값을 보였으며, sucrose는 HHP60 실험군이 유의적으로 가장 낮은 값을 보였다. 총 유리당 
함량은 $\mathrm{HHP0}$ 실험군이 $1,413.36 \mathrm{mg} / 100 \mathrm{~g}$ 으로 유의적으로 가장 높았으며, 고압가열처리가 40 분 이상 지속 시, 총 유리 당 함량이 $1,068.89 \mathrm{mg} / 100 \mathrm{~g}$ 으로 감소하였다. 비휘발성 유기산은, 증숙 및 고압가열 처리 시 succinic acid가검출되 지 않았고, malic acid는 생약호박에 비해 유의적으로 증가 하여 $405.0-428.9 \mathrm{mg} / 100 \mathrm{~g}$ 의 범위를 보인 반면 fumaric aicd 는 큰 폭으로 감소했다. 총 유기산 함량은 유의적인 차이가 나타나지 않았으나 증숙 처리에 의해 그 함량이 증가하는 경향을 보였다. 고압가열 처리에 따른 약호박 페이스트의 관능적 특성차이 검사 결과 40 분간 고압가열 처리한 $\mathrm{HHP} 40$ 실험군의 향, 단맛, 감칠맛 특성이 가장 높게 나타났 으나 유의적인 차이는 없었고, 관능적 기호도 검사 결과 40 분간 고압가열 처리한 HHP40 실험군의 향, 단맛, 감칠맛, 전반적기호도 점수가 가장 높았으나 모두 유의적인 차이는 없는 것으로 나타났다. 위 모든 결과를 종합하여 볼 때, 20 분간 증숙 처리한 약호박 페이스트의 가용성 고형분, 총 유리당 함량, 총 유기산 함량이 가장 높았고, 고압가열 처리 와 그 지속시간에 따른 관능적 특성이 크게 개선되지 않은 것으로 보아 약호박을 이용한 소재를 제조하기 위한 장시간 의 고압가열 처리는 불필요할 것으로 사료된다. 또한, 약호 박은 단호박과 달리 가용성 고형분이 낮고, 단맛 특성, 단맛 기호도 및 전반적 기호도 점수가 낮은 소재인 것으로 나타 나, 기호도를 향상시키기 위해 감미료 등 부재료를 첨가하 여 페이스트로 제조 및 이의 품질특성에 대한 추가적인 연구가 필요할 것으로 보인다.

\section{감사의 글}

본 연구는 농촌진흥청 공동연구사업(과제번호 : PJ011675)의 지원에 의해 이루어진 것으로서 이에 감사드 립니다.

\section{References}

1. Kim MH, Lee WM, Lee HJ, Park DK, Lee MH, Youn SJ (2012) Quality Characteristics of the flesh and juice for different varieties of sweet pumpkins. Korean J Food Preserv, 19, 672-680

2. Oh JY, Kim SM, Yoon JE, Jin YX, Cho YS, Choi YM (2014) Comparison of nutritional compositions of five pumpkin cultivars. Korean J Food Preserv, 21, 808-814

3. Quanhong LI, Caili F, Yukui R, Guanghui H, Tongyi C (2005) Effects of protein-bound polysaccharide isolated from pumpkin on insulin in diabetic rats. Plant Foods Hum Nutr, 60, 13-16
4. Do GP, Lee HJ, Do JR, Kim HK (2012) Antiobestity effect of the Cucubita moschata Duch Extracts in 3T3-L1 adipocyets. Korean J Food Preserv, 19, 138-143

5. Choi CB, Park YK, Kang YH, Park MW (1998) Effects of pumpkin powder on chemically induced stomach and mammary cancers in sprague-dawley rats. J Korean Soc Food Sci Nutr, 27, 973-979

6. Kim MJ, Hong CQ, Nam MH, Lee KW (2011) Antioxidant effects and physiological activities of pumpkin (Cucurbita moschata Duch.) extract from different aerial parts. Korean J Food Sci Technol, 43, 195-199

7. Caili FU, Huan S, Quanhong LI (2006) A review on pharmacological activities and utilization technologies of pumpkin. Plant Foods Hum Nutr, 61, 70-77

8. Jung BM (2004) Nutritional components of yanggeng prepared by different ratio pumpkin. Korean J Soc Food Cookery Sci, 20, 614-618

9. Jung HA, Kim AN, Ahn EM, Kim YJ, Park SH, Lee JE, Lee SM (2011) Quality characteristics of curd yogurt with sweet pumpkin. Korean J Food Preserv, 18, 714-720

10. Park ID (2012) Effects of sweet pumpkin powder on quality characteristics of cookies. Korean J Food Culture 27, 89-94

11. Park JH, Choi JE, Lee JH (2015) Selected physicochemical and consumer preference characteristics of noodles incorporated with sweet pumpkin powder. J Korean Soc Food Sci Nutr, 44, 291-295

12. An YH, Lee IS, Kim HS (2011) Quality characteristics of Sikhye with varied levels of sweet pumpkin during storage. Korean J Food Cookery Sci, 27, 803-814

13. Choo JJ, Shin HJ (2000) Sensory evaluation and changes in physiochemical properties, and microflora and enzyme activities of pumpkin-added Kochujang. Korean J Food Sci Technol, 32, 851-859

14. Kim HS, Park CH, Choi SG, Han BW, Kang KT, Shim NH, Oh HS, Kim JS, Heu MS (2005) Food component characteristics of red-tanner crab (Chionoecetes japonicus) paste as food processing source. J Korean Soc Food Sci Nutr, 34, 1077-1081

15. Son CW, Jeon MR, Kim MH, Kim MR (2008) Quality characteristics and antioxidant activities of green tea garlic paste added calcium. Korean J Food Cookery Sci, 24, 876-881

16. Park BR, Kim NJ, Yoo SM, Han GJ, Kim HY, Han HM, Shin DS, Shin MS (2015) Quality characteristics of sweet-pumpkin paste with different thermal condition 
and sweet-pumpkin latte with various gums. Korean J Food Cook Sci, 31, 304-317

17. Kim SY, Kim HY, Cho MS, Yoo SM (2016) Quality characteristics of Ssamjang Added with Cheonggukjang and various kinds of Jocheong during storage. Korean J Food Cook Sci, 32, 400-412

18. Lee JY, Hwang IG, Park BR, Han HM, Yoo SM, Han GJ, Park JT, Kim HY (2015) Physicochemical characteristics and antioxidant activities of mulberries by greenhouse and open field cultivation in maturation degrees. J Korean Soc Food Sci Nutr, 44, 1476-1483

19. Kim SR, Ha TY, Song HN, Kim YS, Park YK (2005) Comparison of nutritional composition and antioxidative activity for kabocha squash and pumpkin. Korean J Food Sci Technol, 37, 171-177

20. Heo SJ, Kim JH, Kim JK, Moon KD (1998) Processing of purees from pumpkin and sweet-pumpkin. Korean $\mathbf{J}$ Postharvest Sci Technol, 5, 172-176

21. Avila IMLB, Silva CLM (1999) Modelling kinetics of thermal degradation of colour in peach puree. J Food Eng, 39, 161-166

22. Heo SJ, Kim JH, Kim JK, Moon KD (1998) The comparision of food constituents in pumpkin and sweet-pumpkin. Korean J Dietary Culture, 13, 91-96

23. Kim JS, Baek JH, Kim MH, Hong SS, Lee MS (2013) Synthesis of succinic acid from hydrogenation of maleic anhydride. Appl Chem Eng, 24, 650-655

24. Kim BH, Kim DM, Lee SH, Shin HJ (2010) Preparation of coated citric acid for sensory improvement of chocolate products. KSBB J, 25, 443-448
25. Choi DJ, Lee SJ, Kang MJ, Cho HS, Sung NJ, Shin JH (2008) Physichochemical characteristics of black garlic (Allium sativum L.). J Korean Soc Food Sci Nutr, 37, 465-471

26. Shin DB, Hwang JB, Lee YC (1999) Effects of pre-heating on the flavor of garlic. Korean J Food Sci Technol 31, 1583-1588

27. Aida TM, Tajima K, Watanabe M, Saito Y, Kuroda K, Nonaka T, Hattori H, Smith Jr RL, Arai K (2007) Reaction of $\mathrm{D}$-fructose in water at temperature up to $400^{\circ} \mathrm{C}$ and pressures up to $100 \mathrm{MPa}$. J Supercrit Fluid, 42, 110-119

28. Kim EY, Jin Y, Kim KT, Lim TK, Jang M, Cho CW, Rhee YK, Hong HD (2016) Effect of high temperature and high pressure on physicochemical properties and antioxidant activity of Korean red ginseng. Korean J Food Nutr, 29, 438-447

29. Kwon OC, Woo KS, Kim TY, Kim DJ, Hong JT, Jeong HS (2006) Physicochemical characteristics of garlic (Allium sativum L.) on the high temperature and pressure treatment. Korean J Food Sci Technol, 38, 331-336

30. Nicoli MC, Anese M, Parpinel M (1999) Influence of processing on the antioxidant properties of fruit and vegetables. Trends Food Sci Technol, 10, 94-100

31. Hwang IG, Woo KS, Jeong HS (2011) Biological activity and heat treatment processing of foods. Food Sci Ind, 44, 56-65 